\title{
A Proposal for Global-Change Education based on an educational board game: A Planet on the Abyss
}

\author{
Beatriz Pérez-Fernández ${ }^{1}$, Mercedes Vázquez-Vílchez ${ }^{1 *}$, Alicia Fernández-Oliveras ${ }^{1}$ \\ ${ }^{1}$ Departamento de Didáctica de las Ciencias Experimentales, Faculatd de Ciencias de la Educación, \\ Campus la Cartuja, s/n, 18071, Granada, Spain
}

\begin{abstract}
Global change" is a complex term still widely unknown, and often confused with climate change. The Spanish Secondary School Curriculum indicates that the idea of global change is absent. Globalchange components are distributed among different subjects and courses. This scattering of the subject matter hinders students from gaining a cohesive understanding of global change and its implications. The main objective of this proposal is to develop an educational approach aimed at expanding children's knowledge regarding global change, and fomenting awareness of the interrelations between human actions and this environmental crisis. In addition, we seek to aid students in understanding that the adoption of certain practices could help them achieve a sustainable lifestyle. To this end, we have designed and manufactured a prototype board game called "A Planet on the Abyss", with a cooperative play. The pilot study realized have showed that the students recognize that Global Change incorporates more components than climate change and the students related Global Change with an anthropocentric origin and they became to use new terms, such as habitats, ecosystems, deforestation, etc.
\end{abstract}

\section{Introduction}

"Global change" is a complex term still commonly misunderstood, and often confused with climate change. Global change refers to the ensemble of environmental changes provoked by the human activities, especially alterations in the functioning of the Earth's systems. The activities include those that, although local, exert effects beyond the local or regional systems, with repercussions for the global functioning of the Earth. Global change can be divided into five basic components: atmospheric composition, soil uses, climate, biochemical cycles, and biodiversity. These components are interconnected in such way that, if one is altered, the characteristics of the others will also change.

Over the past last 50 years, humans have altered the structure and functioning of the world's ecosystems faster and more widely than in any other period in human history. Ecosystems are particularly affected by large-scale fishing, freshwater use, and agriculture. The extraction of water from rivers and lakes has doubled and the return time from freshwater to the sea has tripled in the last five decades. The discharge of nitrogen, phosphorus, and organic matter into inland and coastal aquatic ecosystems has increased significantly, causing eutrophication problems, with the consequent loss of water quality

\footnotetext{
* Corresponding author: mmvaquez@ugr.es
} 
and build-up of sediments. The result of all this has been a massive and irreversible loss of the life diversity on Earth [1].

In recent years, interest has grown concerning how attitudes and behaviour related to the environmental conservation develop and function, given the relationship between human action and the current situation of environmental crisis. According to experts, we must act responsibly and change our attitudes, behaviour, and values in order to mitigate or solve the environmental problems. Therefore, sustainability implies essential changes in our relationship with the environment, changing our lifestyle and adopting a model based on a new system of attitudes, and values. That is, a person's lifestyle can promote proenvironmental behaviour and the adoption of certain practices can help to lead a sustainable lifestyle [2]. In this sense, recent studies have demonstrated that, in general, people are aware of environmental problems and even recognize that the situation will get worst. However, many people do not realize that our attitudes and behaviour can cause environmental problems and thus do not strive to change their lifestyle [3].

Despite the great amount of information available through the media concerning environmental problems, we still need to assume more responsibility for changing our lifestyle. A change in attitudes and behaviour of new generations requires the participation of the educational system. Therefore, education is key to raising public awareness [2]. From an educational standpoint, one of the most important objectives is for students to understand the nature of environmental problems, so that they will make responsible decisions in the future. However, certain factors make this task difficult. For example, the consequences are not always perceptible (e.g. water depletion of aquifers), while others occur in remote areas (e.g. permafrost melt in the Arctic). Furthermore, some changes are so gradual that they go unnoticed by us (e.g. global warming). This situation is worsening due to diversity of views in scientific debates. There are still scientists who remain sceptical of the idea that global warming is due to human activity, despite the fact that the IPCC (Intergovernmental Panel on Climate Change on Climate Change) concluded in 2007 that the emission of greenhouse gases by human activities is the main cause of climate change [4]. On the other hand, diverse studies have shown that students often confuse the greenhouse effect with the ozone depletion or believe that the greenhouse effect is the cause of global warming [5]. In addition, [6], reviewing the Spanish Secondary School Curriculum found that the idea of global change was absent. Instead, global-change components are taught piecemeal in different subjects and courses. This scattering of the subject matter hinders students from gaining a cohesive understanding of global change and its implications.

The main objective of this proposal is to develop an educational approach aimed at expanding children's knowledge regarding global change, and fomenting awareness of the interrelations between human actions and this environmental crisis. In addition, we seek to aid students in understanding that the adoption of certain practices could help them achieve a sustainable lifestyle. To this end, we have designed and manufactured a prototype board game called "A Planet on the Abyss", with a cooperative play mechanism. The game was submitted to a sample of secondary students in order to evaluate the usability of the game.

\section{Game-Based Learning}

Game-based learning has been widely recognized as one of the most effective approaches for learning for children as well as adults [7-14].

Game-based learning offers students numerous benefits. Games makes learning easier, fun, and engaging and thus more powerful. This active approach invites the student to build knowledge while developing useful skills and positive attitudes. In this way, students can improve their performance and develop complex skills, such as critical thinking. In 
addition, this methodology could encourage students to reflect on what they do, how they do it, and the results involved, rather than simply memorizing information from traditional formats [15]. Therefore, the game-based learning makes use of "learning by doing". This can be extremely powerful, as decision science has shown that first-hand experience is a much better teacher than exposure to information because of the emotional pathways it triggers [16].

Games provide experiences where students are able to simulate complex models or provide a level of control that is not possible in the real world. In this sense, in the learning environment created by the game, the students can experiment and learn by trial and error. The game provides immediate and continuous feedback by which the students identify goals more precisely and with keener motivation. As a result, knowledge and competence will be acquired.

Games are excellent tools for environmental education and engagement. The games used for environmental education encourage foresight, by which students develop the capacity, for example, of envisioning themselves in the future, and foreseeing the consequences of actions at different points in time [17]. Furthermore, these games deliver experiences that tap into a range of human emotions, from fear to joy, wonder and affection, including players' motivation, attitudes, and values [18, 19]. These games stimulate students to find new, more effective solutions that often involve a trial-and-error process, and games can make it easier and less intimidating to identify new strategies [16].

\section{The Game: "A Planet On The Abyss"}

We have designed and manufactured a board game as a proposal for Global-Change Education. "A Planet on the Abyss" is a board game inspired by a cooperative commercial game (Forbidden Island). We designed this game so that the players could develop skills such as: attention, spatial perception, reasoning, and communication (language, discussion, and negotiation).

Figure 1 shows the board game "A Planet on the Abyss". The game consists of saving 4 endangered species (the African elephant, orangutan, caribou, Iberian lynx) on a planet with the risk of global-change consequences. The players (from 4 to 6) have to meet challenges, and devise strategies to save these 4 species, and escape to the International Space Station.

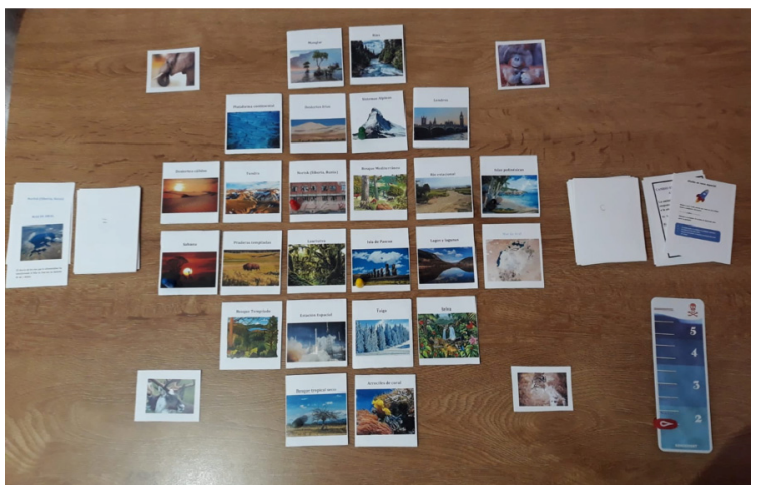

Figure 1."A Planet on the Abyss" board game. The board represents the planet Earth and is composed of 23 ecosystems, each represented by a different tile. The ecosystems are those currently affected by global change: Temperate forest: [20]; Mediterranean Forest: [21, 22]; Alpine systems: [23-26]; Tundra: [27]; Taiga: [28]; Cold Deserts: [29]; Warm deserts: [30]; Laurisilva: [31]; Temperate meadows: [32]; Coral reefs: [33, 34]; Mangrove: [35, 36]; Continental shelf: [37]; Savannah: [38]; Tropical dry forest: [39]; Rivers: [40]; Seasonal rivers: [41]; Lakes and lagoons: [42, 
43]; London: [44]; Polynesian islands: [45, 46]; Norilsk: [47, 48]; Easter Island: [49]; Aral Sea: [50, 51] and Tropical Rainforest [52, 53]

The board represents the planet Earth and is composed of 23 ecosystems, each represented by a different tile. One of the tiles is a spaceship, allowing the players to save the 4 endangered species One side of the tile bears an image of the ecosystem and, on the other side, there is an image of the same ecosystem, but affected by global change. Based on a thorough review, ecosystems were chosen for being currently affected by global change (see Figure 1). Specifically, aquatic species, whether marine or continental, temperate deciduous forests, temperate grasslands, and Mediterranean as well as tropical forests are represented in the game. We have taken into account some coastal habitats, which are disappearing as a result of various human activities, such as mangrove forests and coral reefs. The tundra and boreal forests also are included, although they have undergone less transformation over the last century. However, the ecosystems of these polar and subpolar regions have already begun to be seriously affected by climate change, making them among the most vulnerable to global warming. We have introduced anthropogenic ecosystems, such as London, Polynesia, and Norilsk. In this case, both sides of the tile are the same, because global change has already affected these ecosystems and it is not a prediction, as in the rest of the board tiles.

The game has two packs of cards, one for conservation and one for impacts (Figure 2). Each impact card explains how global change affects a given ecosystem, and implies that the ecosystem tile has to be turned around towards the side affected by the global change. The conservation cards consist of 7 Species cards, 4 Habitat Protection cards, 3 Escaping by Spaceship cards, and 5 Ecologist cards. (Figure 2) The Ecologist cards ask questions or pose challenges regarding global change that the students have to resolve by working together. The questions or challenges set out in the ecology cards require reflective work from the students. We have included 10 Ecologist cards: 2 cards for each component of Global Change. The cards to draw in each turn are 2 from conservation pack and 3 or 1 from impact impacts pack (if the players answer to the Ecologist card is correct, they draw 1 , but if the answer is wrong, they draw 3 ). An endangered species can be saved if a player obtains 4 cards for that species and they are located in the ecosystem where the species lives (Figure 3). The game has a risk marker, which shows the degree of harm caused by of global change (Figure 1). The risk increases whenever a player receives an Ecologist card. When the players reach the top of risk marker and they haven't been able to save all endangered species, they lose.

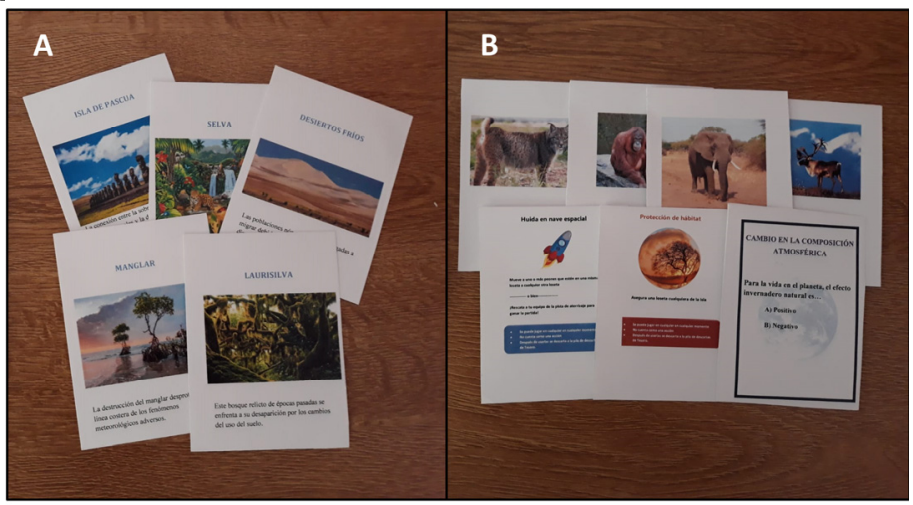

Figure 2. Packs of cards of the game "A Planet on the Abyss", A) Impact cards explain how global change affects a given ecosystem; B) Conservation cards: 7 Species cards, 4 Habitat Protection cards, 3 Escaping by Spaceship cards, and 5 Ecologist cards. 


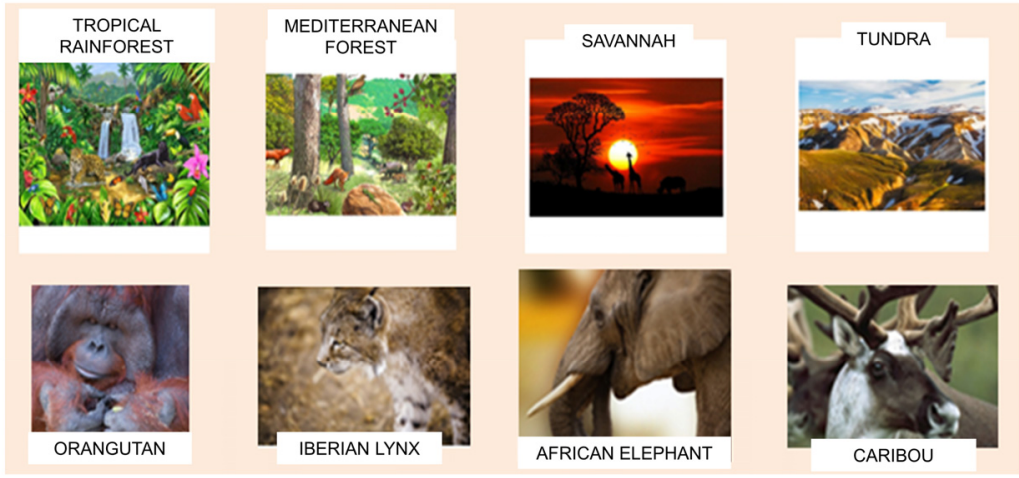

Figure 3. Endangered species and the ecosystem where these species live

The game "A Planet on the Abyss" has three levels: beginner, medium, and advanced level, so that the same group can play up to three times and expand their knowledge about Global Change. Therefore, the students become aware of the consequences that their actions have for our planet, and this can induce them to reflect on how our lifestyle can affect our environment. In addition, the three levels of the game make it adaptable to the different courses of secondary education.

\section{Pilot Study: Procedure and Preliminary Results}

"A Planet on the Abyss" game was submitted to a sample of secondary-school students aged between 16 to 17 years. The pilot study involved 24 students belonging to the 11 th grade of a high school in the city of Granada (Spain). The students were divided into 4 groups of 6 people each. The main goal of the study was to evaluate the usefulness of our board game in fostering the acquisition of skills related to ecological and environmental problems. The pilot study was conducted in a classroom equipped with internet-enabled computers. The game was implemented in two session of one hour each.

The instrument used corresponds to a questionnaire designed ad hoc to this research, with two open questions:

-What is the global change and what are the consequences?

-Is anything you do daily related to the global change? Explain.

We administered the questionnaire, pre- and post intervention, in two sessions separate for one week. The students completed the questionnaire in approximately 15 minutes. During the first session, the students filled out the questionnaire before playing. Then, we explained the instructions and presented the game for the students. During the second session, the students played to the game. The students had to discuss the impact cards, search information and answer the Ecologist cards. The Ecologist cards had to answer after and before the students searched the answer in Internet, so the curiosity of the students would be aroused and they would develop critical thinking.

The perception about the students' experience during the game was positive in many respects. The students showed motivation and enthusiasm, indicating that they liked the game. The game lasted for 1 hour and all the Ecologist cards were answered.

The pre-test results of the questionnaire show that most of the students do not understand exactly what global change is. Many students (33\%) did not know what global change is, $38 \%$ confused global change with climate change, and only the $29 \%$ recognized the human activities as being responsible for these changes. With regard to the second question, only a few students (4\%) answered "no", while 17\% answered "yes" but did not 
enumerate any activities; meanwhile, 79\% answered "yes" and they enumerated some activities, such as recycling, car pollution, waste disposal.

The results collected analysed the game indicated that all of the students knew what global change was and $21 \%$ began to use some of the terms that appeared in the game (ecosystem, habitat, biodiversity, deforestation, etc.). Finally, with respect to the second question, $4 \%$ responded "No" while $91 \%$ answered "Yes " and enumerated some activities.

\section{Conclusion and Future Works}

One of the most important issues in education is to promote sustainability and environmental attitudes in these students of future generations. It is important that students become aware of the danger that our lifestyle can cause to the whole ecosystem. In this context, it is essential not only to supply information but also improve human behaviour. Game-based learning is one of the most effective approaches for learning and proves to be excellent for environmental education and engagement. "A Planet on the Abyss" is a collaborative game that can improve the knowledge of global change in the students. Our preliminary data indicate that, after playing the game, the students recognize that global change includes more components than climate change; also, the students related global change to human origin and they began to use new terms, such as habitat, ecosystem, deforestation, etc..

In future works, we will expand this research to perform a validation study in order to measure motivation, usability, and the learning effectiveness.

\section{Acknowledgements}

The authors would thank the students and teachers of the 11th I.E.S. Mariana Pineda in Granada (Spain) involved in the pilot study. The authors also express their appreciation to the University of Granada, Spain, for financing research project PPJI2018-06 and teachinginnovation project PID18-363, under Alicia Fernández-Oliveras coordination. Finally, we also would express our acknowledgement for the financial support to the group HUM-613 of the Universidad de Granada.

\section{References}

1. C.M. Duarte (Coord., J.C. Abanades, S. Agustí, S. Alonso, G. Benito, J.C. Ciscar, C., F. Valladares), Cambio global. Impacto de la actividad humana sobre el sistema Tierra (2006), https://doi.org/10.1017/CBO9781107415324.004

2. M. Jaén, P. Barbudo, Rev. Eureka Enseñ. Divul. Cien, 7, 247-259 (2010)

3. P.A., Meira Cartea, M. Arto Blanco, P. Montero Souto, (2009). La sociedad ante el cambio climático. Conocimientos, valoraciones y comportamientos en la población española. Vasa. (2009)

4. I. García-Rodeja Gayoso, I., G. Lima de Oliveira, Enseñanza de Las Ciencias, 30, 195-218 (2012)

5. P. Punter, M. Ochando-Pardo, J. Garcia, (2011). International Journal of Science Education,33,447-464 2011. https://doi.org/10.1080/09500693.2010.492253

6. B. Pérez Fernández, (2018). Tesis Fin de Máster Oficial Universitario en Profesorado de Enseñanza Secundaria Obligatoria y Bachillerato, Formación Profesional y Enseñanzas de Idiomas, Universidad de Granada (2018). 
7. M. Bakhuys Roozeboom, G. Visschedijk, E., Oprins, Br. J. Educ. Technol, 48, 83-100 (2015)

8. S. Barab, B. Scott, S. Siyahhan, R. Goldstone, A. Ingram-Goble, S. Zuiker, J. Sci. Educ. Technol, 18, 305-320 (2009). doi:10.1007/s10956-009-9171-5

9. S., Chen, D. Michael, Thomson Course Technology, USA (2005)

10. P. Di Bitonto, T. Roselli, V. Rossano, E. Frezza, E. Piccinno, The 18th International Conference on Distributed Multimedia Systems, Miami Beach, USA, KSI Press, Skokie, Illinois, pp. 139-143 (9-11 August 2012).

11. M. Jun Kiat Ong, Master of Science in Applied Psychology, University of Canterbury (2013).

12. P.M. Kato, S.W. Cole, A.S. Bradlyn, B.H. Pollock, Pediatrics, 122, 305-317 (2008)

13. M. Prensky, Digital Game-Based Learning, McGraw-Hill, New York (2001)

14. A.L. Reschly, S.L. Christenson, Handbook of Research on Student Engagement, 3-19 (2012).

15. K. Squire, Educ. Res., 35, 19-29 (2006).

16. J. Mendler de Suarez, P. Suarez, C. Bachofen, (eds), Boston Univ., The Frederick S. Pardee Center for the Study of the Longer-Range Future (2012).

17. A. Wiek, D. Iwaniec, Sustain. Sci., 9, 497-512 (2014).

18. K. Squire, Int. J. Intell. Games \& Simulation, 2, 49-62 (2003).

19. K. Salen, E. Zimmerman, MIT Press (2004).

20. L. Hernández, Ecosistemas, 25, 112-115 (2016).

21. L. Matías, R. Zamora, J. Castro, (2015). Los Bosques y La Biodiversidad Frente Al Cambio Climático: Impactos, Vulnerabilidad y Adaptación En España, 1, 215-224 (2015). https://doi.org/10.1007/s13398-014-0173-7.2

22. J. Cabello, A.J. Castro, Estado y tendencia de los servicios de los ecosistemas de Zonas Áridas de Andalucía, 64, (March 2015).

23. F. Fillat, A.J. Aguirre, F. Pauné, C. Fondevilla, Evaluación de los ecosistemas. Ambienta, 116-133 (March 2012).

24. J.M. Vide, Investigaciones Geográficas, 49, 51-63 (2009).

25. V. Barros, Libros del Zorzal, Buenos Aires, Argentina (2007)

26. J. F. Isaza Delgado, D. Campos Romero, Fundación Universidad de Bogotá Jorge Tadeo Lozano (2007)

27. J.J. Camarero, J. Peñuelas, E. Gil-Pelegrin, F. Lloret, L. Corcuera, L., Ecología Del Bosque Mediterráneo, 397-423 (2004).

28. M. F., André, O. Anisimov, Tundra and permafrost-dominated taiga. Geomorphology $\begin{array}{llll}\text { and } & \text { Global } & \text { Environmental }\end{array}$ https://doi.org/10.1017/CBO9780511627057.014.

29. D. Ojima, T. Chuluun, Fragmentation in semi-arid and arid landscape, Dordrecht: Springer Netherlands, 179-193 (2008).

30. A. Herrera, W. Tezara, O. Marín, E. Rengifo, C. Ballestrini, M.D. Fernández, R. Colombo, Memorias Del Instituto de Biología Experimental, 185-188 (4 January 2005).

31. J.J. Bacallado, (1976). Biogeography and Ecology in the Canary Islands, The Hague 1, 413-436 (1976). https://doi.org/10.1007/978-94-010-1566-0_14. 
32. H.F. Howe, B. Zorn-Arnold, A. Sullivan, J.S. Brown, Ecology, 87, 3007-3013 (2006).

33. J.L. Carballo, E. Bautista-Guerrero, H. Nava, J.A. Cruz Barraza, I. Memorias Del Primer Taller de La RED CYTED BIODIVMAR. La, 183-193 (2016) https://doi.org/10.1017/CBO9781107415324.004.

34. B. Bádenas, M. Aurell, Enseñanza de Las Ciencias, 21-28 (January 1999).

35. F. Pannier, Ciencia, 43, 111-113 (1992).

36. R. Seppala, B. Alexander, P. Katila, IUCN - IUFRO - Comunicación para el Desarrollo - FORMIN. Ministerio de Relaciones Exteriores de Finlandia Inión Internacional de Organizaciones de Investigación Forestal (March 2009).

37. J. Rodríguez, A. Reul, Biodiversidad y servicios de los ecosistemas marinos (2010).

38. C. Conde, S.O. Saldaña-Zorrilla, Revista Ambiente y Desarrollo, 23, 23-30 (2007).

39. M. Vela-Vargas, J. Pérez-Torres, Chiroptera Neotropical, 1089-1100 (18, July, 2012).

40. A. Serdio, C. García De Leániz, S. Consuegra, Consergería de Ganadería, Agricultura y Pesca, Gobierno de Cantabria, 237-250 (2001).

41. V. Burg, Swiss Federal Institute of Technology Zurich (ETH Zurich) (2007). https://doi.org/10.3929/ETHZ-B-000225616.

42. J.A. Camargo, A. Alonso, Revista Ecosistemas, 16, 98-110 (2007). https://doi.org/10.7818/457.

43. R. Quirós, El Agua en Iberoamérica: Acuíferos Lagos y Embalses. CYTED. Subprograma XVII. 44. Aprovechamientos y Gestión de Recursos Hídricos, 12 (2000).

44. C. Fresneda, Alerta en Londres por el desbordamiento del Támesis | Internacional | EL MUNDO. El Mundo (2014, February 10).

45. F. Hernández Durán, M. Sandoval Chavarro, Morfolia, 9, 11-12 (2017).

46. A. Simas, J. Magrath, H. Reid, International Institute for Enviroment and Development, 3, 1-40 (2004).

47. D.A. Streletskiy, A.B. Sherstiukov, O.W. Frauenfeld, F.E. Nelson, Environmental Research Letters, 10, (2015). https://doi.org/10.1088/17489326/10/12/125005.

48. N.I. Shiklomanov, D.A. Streletskiy, V.I. Grebenets, L. Suter, Polar Geography, 40, 273-290 (2017). https://doi.org/10.1080/1088937X.2017.1329237.

49. V. Rull, N. Cañellas-Boltà, O. Margalef, S. Pla-Rabes, A. Sáez, S. Giralt, Frontiers in Ecology and Evolution, 4, 1-4, (March, 2016). https://doi.org/10.3389/fevo.2016.00029.

50. J. Williams, Ecología Política (2007, June).

51. S. O'Hara, Water Policy, 2, 365-384 (2000). https://doi.org/10.1016/S13667017(00)00010-6

52. D. Miliband, Malaysan Diary (14 ${ }^{\text {th }}$ July 2006$)$.

53. C. Nellemann, L. Miles, B.P. Kaltenborn, M. Virtue, H. Ahlenius (eds), United Nations Environment Programme, GRID-Arendal, Norway, (2007). 